\title{
Modelling the future spread of native and alien congeneric species in subterranean habitats - the case of Meta cave-dwelling spiders in Great Britain
}

\author{
Stefano Mammola ${ }^{1,2}$ \\ ${ }^{1}$ Laboratory of Terrestrial Ecosystems, Department of Life Sciences and Systems Biology, University of Torino, Torino, Italy \\ ${ }^{2}$ IUCN SSC Spider and Scorpion Specialist Group, Torino, Italy
}

\begin{abstract}
The threshold zones between the epigean and hypogean environments are generally characterized by less harsh ecological conditions than deep subterranean habitats, and usually support a greater abundance of organisms. Transitional habitats such as these should be more easily colonised by alien species, especially by those possessing exaptations suitable for subterranean life. In spite of this, few studies have been conducted to unravel the ecological dynamics between native and alien species in the habitats situated at the epigean/hypogean interface. A unique test case is offered by cave-dwelling Meta orb-weaver spiders in Great Britain (Araneae: Tetragnathidae). One species, M. menardi, is a widespread native, whilst $M$. bourneti is believed to be a recently introduced (1940s) species, that has since become established in the south-eastern part of the country. Species distribution models (SDM) were used to predict current and future habitat suitability for the two species, generating hypotheses regarding their distribution in different global warming scenarios. Model projections indicate that the two species respond to similar environmental variables. Seasonal temperature variations at the surface and elevation are the main factors explaining the distribution of both species, whereas annual precipitation, daily temperature range and limestone distribution contributed little to the model performance. It is predicted that due to climate change, there will be poleward shifts in the ranges of both species. However, the native species M. menardi will primarily be able to exploit suitable areas which will appear northward to their current distribution, and M. bourneti will colonise empty niches left available by its congeneric. The analytical framework employed in this paper may be easily adapted to other subterranean systems and species, stimulating future studies focusing on the distribution of native and alien species in extreme environments.
\end{abstract}

Keywords: $\quad$ global warming, species distribution models, cave, alien species, MaxEnt, subterranean biology Received 22 May 2017; Revised 28 August 2017; Accepted 28 August 2017

Citation: Mammola S., 2017. Modelling the future spread of native and alien congeneric species in subterranean habitats - the case of Meta cave-dwelling spiders in Great Britain. International Journal of Speleology, 46 (3), 427-437. Tampa, FL (USA) ISSN 0392-6672 https://doi.org/10.5038/1827-806X.46.3.2134

\section{INTRODUCTION}

As a result of human activity during historical times, deliberate or accidental transport across natural barriers has altered the natural dispersal rate of many organisms including several invertebrate species (Hulme, 2009; Blackburn et al., 2011). Species transferred to new biogeographic areas may ultimately establish viable populations capable of reproducing therein and, eventually, of interacting and competing with native species. However, not all habitats are equally likely to be colonized by alien species (Pyšek et al., 2010).

Although in the last few decades the presence of certain alien species in terrestrial and marine caves has been observed (e.g., Martin \& Oromi, 1984; Elliot, 1992; Oromi \& Martin, 1992; Taylor et al., 2003; Howarth et al., 2007; Mazza et al., 2014; Wynne et al., 2014; Chomphuphuang et al., 2016; Gerovasileiou et al., 2016; Price, 2016), deep subterranean habitats are generally regarded as significant ecological filters for the establishment of alien species. Conversely, threshold zones at the epigean/hypogean interface are often characterized by less harsh ecological conditions than deep subterranean habitats, and should theoretically be more readily colonised by alien species.

Settled at the blurry interface between the outer world and the deepest subterranean sectors, epigean/ hypogean ecotones are usually the most biologically 
diverse subterranean habitats (Prous et al., 2004, 2015; Novak et al., 2012). They are subjected to daily and seasonal variations in microclimatic conditions, light availability, and, most of all, trophic resources (Culver \& Pipan, 2009). As a rule of thumb, these conditions should facilitate the establishment of alien species possessing exaptations suitable for subterranean life - e.g., moss- and litter-dwelling arthropods. For instance, almost $20 \%$ of the terrestrial invertebrates recorded in caves in Maritime Canada, which are mostly shallow and food-rich, are believed to be recently introduced aliens of European origins (see Moseley, 2007, 2009a). Similarly, a number of alien species have been reported in food-rich guano caves in Asia (Price, 2016); for instance, the massive presence of Periplaneta cockroaches (Blattodea) is a serious ecological problem in tropical caves (Price \& Steiner, 1999).

Despite its importance, I am not aware of any quantitative studies which have been conducted to model the potential distribution and spread of alien invertebrate species in subterranean habitats at a regional scale - but see Flory et al. (2012) and Escobar et al. (2014) for two examples of fungi. An interesting test case for a similar analysis is offered by Meta spiders in Great Britain (Araneae: Tetragnathidae). The genus Meta is represented in Europe by Meta bourneti Simon and M. menardi (Latreille). Both are medium size orb-weaver spiders, well known among subterranean biologists and cavers as ubiquitous inhabitants of the cave twilight zone. They are regarded as troglophiles (sensu Trajano \& Carvalho, 2017), representing specialised parietal predators in most European caves (Moseley, 2009b; Mammola \& Isaia, 2014). In Great Britain both species are present (Spider Recording Scheme, 2017; hereinafter SRS). $M$. menardi is native to the island, being distributed across its whole latitudinal range. Conversely, in Britain $M$. bourneti is restricted mostly to the southeast where it is believed to be an introduced alien species.

The first documentation of $M$. bourneti in Britain dates back to 1941, when Lieut. R. Gibson Jarvie discovered a healthy population in a culvert near to his home at Gedding, Mid Suffolk. He sent a specimen to the British Natural History Museum for identification, which later turned out to be $M$. bourneti. While reporting this interesting discovery, Browning \& Thams (1944: p. 95) observed that "[Meta bourneti] may have been imported from France with wine, as is likely to have occurred frequently in the case of Physocyclus simoni Berl. [later transferred to gen. Psilochorus]". However, it is not possible to be certain about this introduction, without a large scale genetic screening of island and continental populations. Various authors consider it as the most likely explanation for the presence of $M$. bourneti in England (Gasparo \& Thaler, 2000; Mammola \& Isaia, 2014, 2017a). According to Gasparo \& Thaler (2000), this point of view is further supported by the fact that in England the species occurs prevalently in artificial underground situations, such as tunnels, culverts and drainage inspection chambers (SRS, 2017).
In this contribution, spatial models were used to estimate the current and future range of Meta spiders in the British Isles. The aim of the study is to predict the habitat's suitability for both native and alien species and to investigate the future re-arrangement of their distribution ranges in light of global warming scenarios.

\section{MATERIAL AND METHODS}

\section{Input data}

\section{Occurrence points}

Species distribution models (SDMs) were used to model Meta range dynamics in light of climate change. Geo-referenced occurrences of $M$. bourneti and $M$. menardi were extracted from the UK Spider Recording Scheme in 2015 (SRS, 2015; dots in Fig. 1 and 2). In Great Britain, M. menardi is widely but patchily distributed across the whole country, whereas $M$. bourneti is found in southern England, with only two records from Wales (SRS, 2015).

Most occurrence datasets of cave-dwelling species are prone to be spatially biased. For instance, investigated subterranean habitats are often concentrated in certain areas, such as karst (Christman \& Culver, 2001), and there may also be spatial variations of sampling efforts related to the presence/absence of scientists and recreational cavers able to investigate underground habitats. These issues may result in autocorrelation patterns in spatial datasets, if the occurrences of cavedwelling species are unevenly distributed in the environmental space, containing "artificial" gaps and areas of higher density (see e.g., clumped dots in Fig. 2).

In order to take into account this potential issues (Phillips et al., 2009; Syfert et al., 2013), a sampling grid at the resolution of the environmental predictors (30"; see below) was generated. Rather than using raw point-locality occurrence data of the two species of Meta, within each cell in of the grid, occurrence data were aggregated to avoid inflation of the numbers of presences as an effect of spatial sampling heterogeneity.

\section{Environmental predictors}

To represent the subterranean conditions, both topographical - presence of carbonate rocks, elevation data - and bioclimatic variables were employed (see Table 1 for details). A shapefile of carbonate extent for the study area was obtained from the World Map of Carbonate Rock Outcrops (http://web.env.auckland. ac.nz; version 3.0, accessed on 10 May 2017). The map was converted into a binary raster and included among the model predictors as a categorical covariate. Bioclimatic variables and elevation data at a resolution of 30" were downloaded from the WorldClim website (1950-2000; Hijmans et al., 2005). Analogous data layers at the same spatial resolution were obtained for future conditions. Future data represent downscaled and calibrated climate projections for the year 2070 from three different general circulate models (GCMs; namely: CCSM4, BCC-CSM1-1, MIROC5) and two 


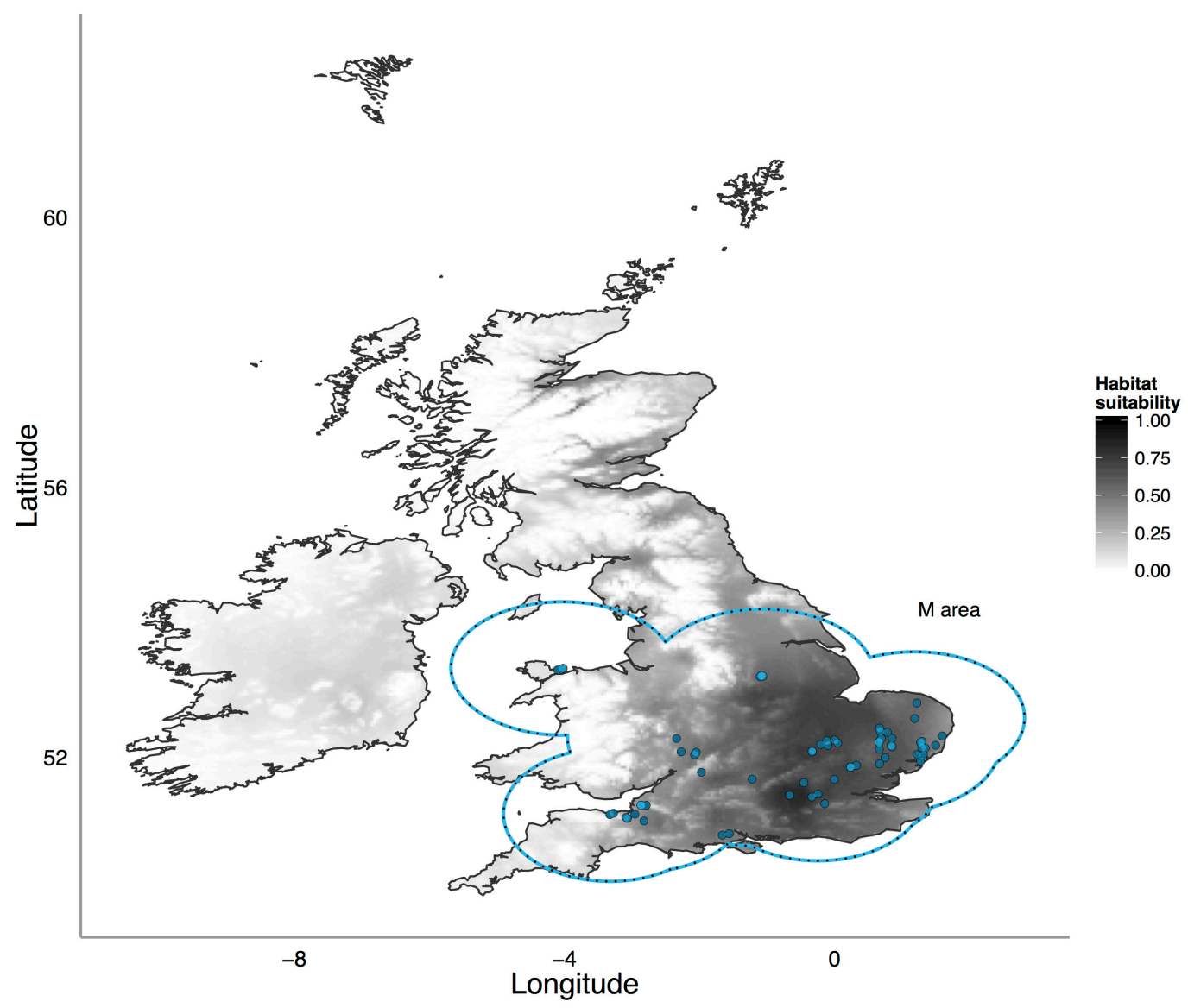

Fig. 1. Current potential distribution map for Meta bourneti based on present-day climatic conditions. Shaded grey areas are modelled suitable conditions. Dots are occurrences of $M$. bourneti - not corrected for spatial correlation. The $\mathbf{M}$ area used to calibrate the model is highlighted.

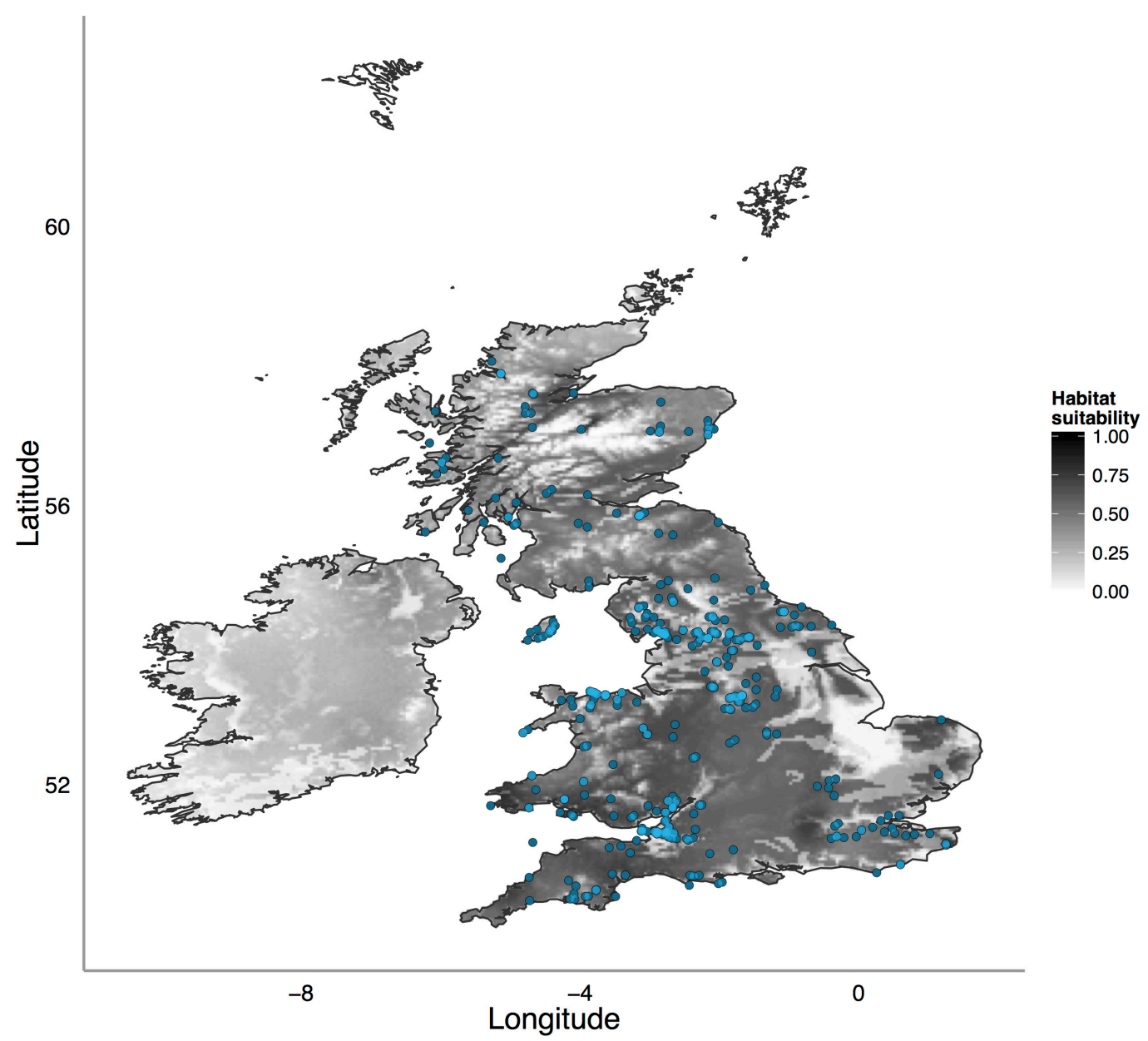

Fig. 2. Current potential distribution map for Meta menardi based on present-day climatic conditions. Shaded grey areas are modelled suitable conditions. Dots are occurrences of $M$. menardi - not corrected for spatial correlation. 
Table 1. Variables used in the Species distribution models and their relevance to represent subterranean conditions. Permutation importance (and percent contribution) of each variable in constructing the final model is reported (sensu Phillips, 2011).

\begin{tabular}{|c|c|c|c|}
\hline Variable & Relation with the subterranean conditions & $\begin{array}{c}\text { Permutation } \\
\text { importance } \\
\text { (M. bourneti model) }\end{array}$ & $\begin{array}{c}\text { Permutation } \\
\text { importance } \\
\text { (M. } \text { menardi model) }\end{array}$ \\
\hline $\begin{array}{l}\text { Temperature Diurnal } \\
\text { Range }(\mathrm{Bio02})\left({ }^{\circ} \mathrm{C}\right)\end{array}$ & \multirow{2}{*}{$\begin{array}{l}\text { Bio02 and Bio07 represent proxies of the } \\
\text { daily and seasonal excursion found in the vicinity } \\
\text { of the cave entrance (Badino, 2010) and in other } \\
\text { Superficial Subterranean Habitats (Pipan et } \\
\text { al. } 2011 \text {; Mammola et al., 2016b), where } \\
\text { Meta spiders preferentially thrive. }\end{array}$} & $1.2(0.5 \%)$ & $13.8(13.7 \%)$ \\
\hline $\begin{array}{l}\text { Temperature Annual } \\
\text { Range }(\mathrm{Bio07})\left({ }^{\circ} \mathrm{C}\right)\end{array}$ & & $61.4(53.7 \%)$ & $45.9(38.5 \%)$ \\
\hline $\begin{array}{l}\text { Annual Precipitation } \\
\text { (Bio12) (mm) }\end{array}$ & $\begin{array}{l}\text { Infiltrating rain water is considered to be the } \\
\text { primary factor determining the general climatic } \\
\text { conditions found underground (Badino, 2010). In } \\
\text { addition, rain water represent an important route } \\
\text { for organic materials to enter hypogean ecosystems. } \\
\text { Therefore, Bio12 may represent a proxy for external } \\
\text { energy inputs (see also Bregović \& Zagmajster, 2016). }\end{array}$ & $3.7(1.7 \%)$ & $13.2(7.1 \%)$ \\
\hline Altitude (m) & $\begin{array}{l}\text { Elevation range is considered to be one of the } \\
\text { simplest surrogate of topographic heterogeneity } \\
\text { (Zagmajster et al., 2014; Eme et al., 2015, } \\
\text { 2017; Bregovic and Zagmajster, 2016), thus } \\
\text { representing a proxy for habitat availability. } \\
\text { This variable also influence the general thermal } \\
\text { conditions (Badino, 2010). }\end{array}$ & $32.2(41.5 \%)$ & $25.7(31.9 \%)$ \\
\hline $\begin{array}{l}\text { Carbonate substrates } \\
\text { extent }\end{array}$ & $\begin{array}{c}\text { It represent a proxy of the general availability } \\
\text { of subterranean habitats in carbonate } \\
\text { substrates (Christman \& Culver, 2001, } \\
\text { Christman et al., 2016). }\end{array}$ & $1.5(2.6 \%)$ & $1.4(8.8 \%)$ \\
\hline
\end{tabular}

representative concentration pathways (rcp), namely a low-emission (rcp 2.6) and a high-emission (rcp 8.5) scenarios. Multiple GCMs were employed to take into account variations and uncertainty between mathematical simulations (Diniz-Filho et al., 2009).

Multi-collinearity among continuous covariates was checked by means of Pearson $r$ correlation, setting a threshold for collinearity at $r> \pm 0.7$ (Zuur et al., 2010). Variables highly correlated were excluded to avoid model overfitting.

\section{Species distribution models}

SDMs for the two species were constructed with MaxEnt (Phillips et al., 2006) in the dismo $\mathrm{R}$ package (Hijmans et al., 2014). MaxEnt is a machine-learning statistical technique which relies on the principle of maximum entropy. It allows the user to estimate the potential distribution of a species, by fitting the probability distribution of maximum entropy for presences-only points, constrained in a set of environmental explanatory variables (Phillips et al., 2006; Elith et al., 2011).

SDMs were calibrated within the accessible area - $\mathbf{M}$ area - representing the geographic extent hypothesized to fall within the long-term dispersal and colonisation potential for a certain species over its evolutionary history (Barve et al., 2011; Peterson et al., 2011; Saupe et al., 2012). In the case of Meta menardi, which is expected to have a long evolutionary history on the Britain's landscape, dating back at least to the Last Glacial Maximum, the calibration area was set to coincide with the island territory. On the other hand, it has been suggested that when a species has newly arrived on a landscape, its $\mathbf{M}$ can be estimated only based on dispersal characteristics (Barve et al., 2011). It has been shown that during the early stages of their life cycle, Meta spiders are able to disperse outside the cave by means of ballooning - i.e., an air-borne passive dispersal (Smithers \& Smith, 1998; Smithers, 2005b; Mammola \& Isaia, 2014). Therefore I assumed a linear distance of $500 \mathrm{~km}$ to represent a good approximation of the dispersal potential of Meta spiders, at least over a few generations (see discussion in Mammola \& Isaia, 2017a). For M. bourneti, the $\mathbf{M}$ area was thus constructed by buffering the occurrence records by a radius of $500 \mathrm{~km}$ via the circle R command (Hijmans, 2014) and combining all circles in a final shape (Fig. 1).

MaxEnt models were fitted with default parameters. To generate the present-day prediction, 50 bootstrap replicates of the model were ran, and the median output was used in the analyses. For each bootstrap replicate a random partition of $20 \%$ of the occurrence points was used for model validation. Model performance was evaluated on each random partition of occurrence points, via the Area Under the Curve (AUC) of the Receiver Operating Characteristic (ROC) plot (Fielding \& Bell, 1997) and the true skill statistics (TSS; Allouche et al., 2006). Given that the two species never coexist within the same subterranean habitat (Mammola \& Isaia, 2014), for model evaluation, the occurrence points of one species were considered true absence of the other species, and vice versa.

A final model for each species was generated using the same parameters and calibrated with the complete occurrence data set for each species. In turn, the model was transferred into each future GCMs and the median values for each GCM combination was calculated. The niche overlap between the two species was calculated both in the present and each future projection, using the similarity statistic I and the Schoener's D (Warren et al., 2009). Both indexes range from 0 (niche models have no overlap) to 1 (niche models are identical). 


\section{RESULTS}

Overall, 424 occurrence records were obtained from the UK Spider Recording Scheme - 64 unique occurrences for Meta bourneti (Fig. 1) and 360 for $M$. menardi (Fig. 2). The overall pattern of occurrences suggested a geographically broad distribution of Meta menardi, with more intense sampling efforts in southern and central England. Sampling is much more sparse in the northernmost countries. Occurrences of $M$. bourneti are mostly limited to southern-eastern England.

The predictive performance of the MaxEnt model was high both for Meta bourneti (mean AUC \pm s.d. = $0.9512 \pm 0.043$; mean TSS \pm s.d. $=0.6734 \pm 0.039$ ) and $M$. menardi $(0.9237 \pm 0.085$; mean $\mathrm{TSS} \pm$ s.d. $=$ $0.6212 \pm 0.058)$. The contribution of each variable in constructing the final models is reported in Table 1. All variables introduced in the models had pairwise Pearson correlation coefficients $< \pm 0.7$. Overall, altitude and temperature annual range (Bio07) explained over $90 \%$ of the model of $M$. bourneti, and over $80 \%$ of that of $M$. menardi. Altogether, the other variables accounted for the remaining percentage of the model. The suitable areas predicted by the current models are coherent with the documented distribution of the two species (see SRS, 2017). Present-day projections identified suitable areas for M. bourneti across southern-eastern England (Fig. 1), whereas the most suitable areas for $M$. menardi were found throughout the country, with higher probability of occurrence in the westernmost part of Britain (Fig. 2). Both metrics employed indicated a large overlap in the niches of the two species $(I=0.88 ; \mathrm{D}=0.62)$.

For each future emission scenario, in general projections indicated a slight northward shift in the range of distribution - here modelled as habitat suitability - of the two species (Fig. 3). Concerning $M$. menardi, greater variations are observed at higher emission scenarios, whereas for the low emission scenario the habitat suitability will only slightly vary. For $M$. bourneti, a northward shift is observed for both emission scenarios. A general reduction in bioclimatic suitability is also observed in Southern England for the high-emission scenario. In the present distribution, slightly lower niche overlaps in the future range of distribution are predicted (Low emission scenario: $\mathrm{I}=0.77, \mathrm{D}=0.49$; high emission scenario: $\mathrm{I}=0.70$, $\mathrm{D}=0.43)$, possibly indicating a differential expansion of the distribution of the two species in face of future climatic variations.

\section{DISCUSSION}

\section{Environmental drivers of the current distribution}

Whilst in recent years there have been a number of studies documenting the ecological requirements of Meta spiders at a local scale (Novak et al., 2010; Mammola \& Isaia, 2014; Manenti et al., 2015; Mammola et al., 2016a; Lunghi et al., 2017), the environmental drivers of their broad distributions are still poorly documented. In the only attempt to model the distribution of these species at a continental scale, large scale climatic variables and the competition between the two species were considered as the main factors explaining their broad distribution patterns (Mammola \& Isaia, 2017a).

In this study, specific predictors representing proxies of the ecological condition in which the Meta cave-dwelling spiders live, were used to model their distribution at a regional scale (Table 1). Seasonal climatic variability in the vicinity of the surface (Bio07), rather than daily climatic variability (Bio02), emerged as the main driver of the general distribution of the two species. This result is well explained if we take into account the general preference of these spiders for the subterranean habitats in the vicinity of the surface (Novak et al., 2014), where the external meteorological variability still exerts a seasonal influence on the general microclimate. Also, this result is in direct accordance with observations made at a local scale - single cave systems, - pointing out an influence of seasonal climatic variations in the spatial distribution of the spiders within the cave (Mammola et al., 2016a; Lunghi et al., 2017).

Topographic heterogeneity - here approximated using elevation data (see Zagmajster et al., 2014; Eme et al., 2015, 2017; Bregović \& Zagmajster, 2016) - rather than the presence of carbonate substrates, emerged as the second most important factor in constructing the distribution models (Table 1). A strong correlation with limestone areas would indeed only be expected in calciphilous invertebrate species (e.g., certain species of Gastropoda), or those largely restricted to natural caves. In this respect, it is well documented that, aside from caves, Meta spiders are able to thrive in a variety of dark and moist habitats, such as sea caves, mines, cellars, culverts, drainages, railway tunnels, hollow trees, animal burrows, boulder fields and other rocky crevices (Smithers, 1995, 2005a, 2005b; Růžika, 1999; Harvey et al., 2002; Růžika \& Klimeš, 2005; Mammola \& Isaia, 2014; Mammola et al., 2016a; Moseley \& Proctor, 2017). This high ecological plasticity may explain why the influence of the geological substrate, in constructing the model, is only limited and, in parallel, why topographic heterogeneity is important in explaining the distribution of these spiders. In addition, elevation is likely to act as a surrogate of mean annual temperature, as it directly influences the general thermal conditions found underground (Badino, 2010).

When considering the model of $M$. bourneti, the contribution of the other variables was negligible. Conversely, a slight contribution of the precipitation regime (Bio12) and the daily temperature variations (Bio02) were detected when considering the model of $M$. menardi. This result is in accordance with the low tolerance to drought and higher temperature variations documented in this species (Mammola \& Isaia, 2014; Manenti et al., 2015). The fact that the rainfall regime plays a relatively unimportant contribution in the models may also be explained by considering the extent of the study area: it is likely that annual rainfall will became more significant at a greater geographical scale, if drier climates were to be included in the model calibration area. 

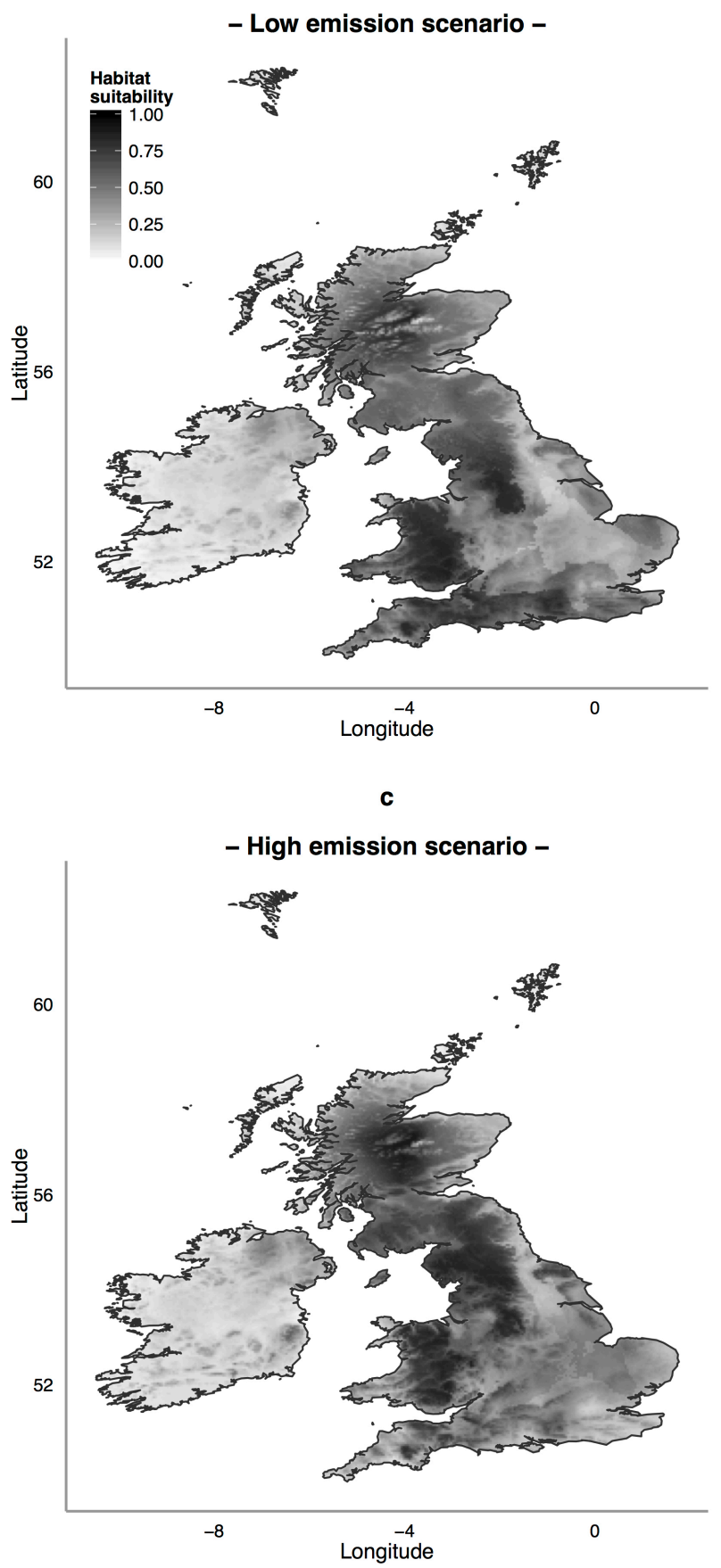

b
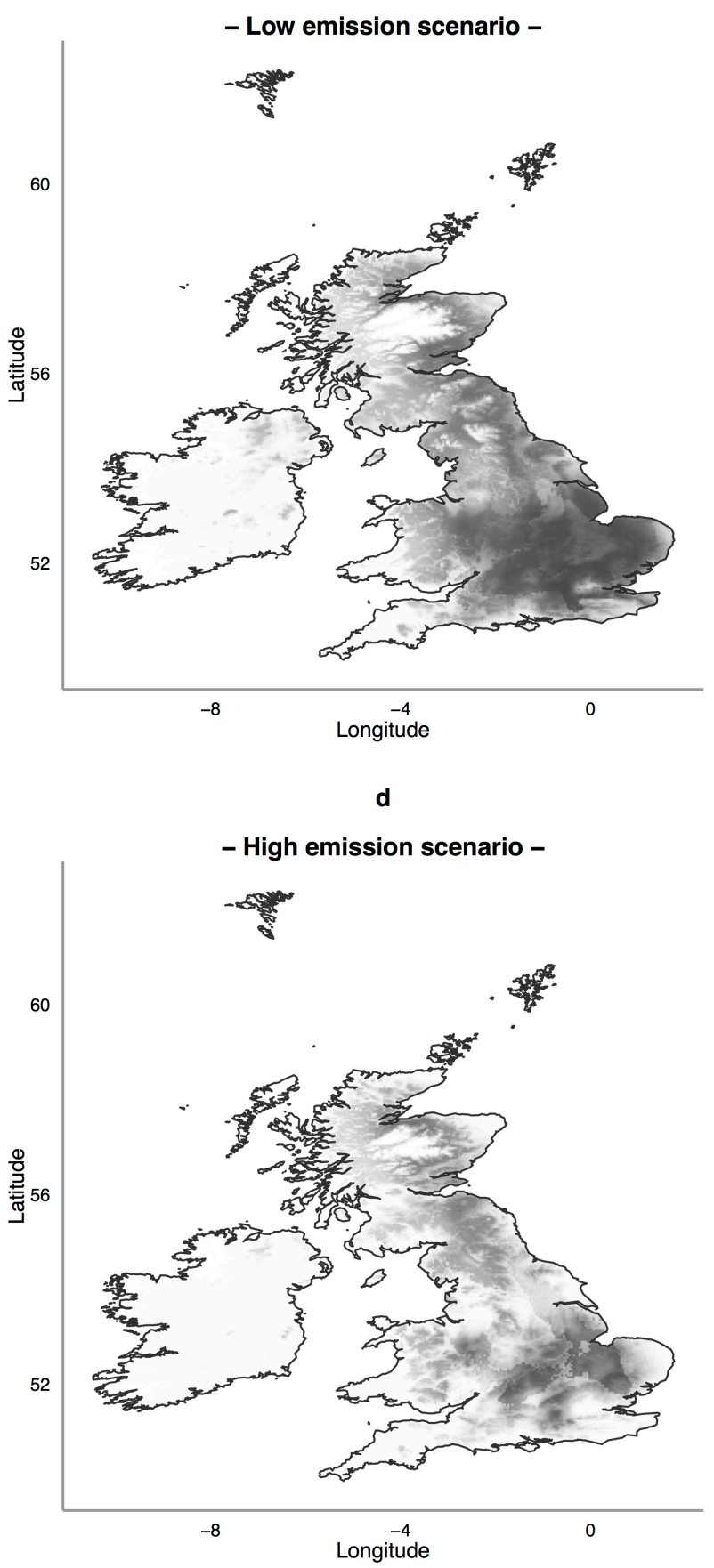

Fig. 3. Projected future habitat suitability for Meta bourneti $(b, d)$ and $M$. menardi $(a, c)$ in 2070 according to the two Representative Concentration Pathways ( $\mathrm{rcp}$ ) considered in the work. Shaded grey areas are modelled suitable conditions.

\section{Future distribution}

Climate change is causing species in the temperate zone of the northern hemisphere to move north and to higher elevations (e.g., Walther et al., 2002; Brommer, 2004; Zuckerberg et al., 2009; Chen et al., 2011). If species distributions were to shift in the same direction and at the same rates, there would be no range overlaps and interactions among previously isolated species (Warren et al., 2016). However, if species were to move at different rates in response to climate change, shifts in distributions may bring closely related species to come in contact (Krosby et al., 2015), as in the case of Meta spiders across continental Europe (Mammola \& Isaia, 2017a).

In England, the distribution of these spiders represents a peculiar case because, as detailed in the introduction, $M$. bourneti has been most likely introduced. In continental areas where the natural ranges of the two species overlap, it has been demonstrated that they display complete niche partitioning through conditional differentiation (Mammola \& Isaia, 2014). Although the SDM projections evidence large overlaps in the niche of the two species ( $c f$. Fig. 1 and 2; see also niche overlaps metrics), the occurrence in syntopy of the two species has never been documented in England (SRS, 2017). For instance, Milner (2013) pointed out that in the London area the localities of $M$. bourneti and $M$. menardi are clearly separated by the river Thames.

Model projections suggest that the distribution of Meta spiders will be affected by climate changes, with emergence of new suitable areas north of their current range. It is expected that, due to dispersal limitation in epigean habitats, most subterranean 
species will be unable to cope with climate change by shifting their distribution (Sánchez-Fernández et al., 2016; Mammola \& Isaia, 2017b; Mammola et al., 2017). Meta spiders represent unusual subterranean organism in this regard: the possibility to colonise hypogean habitats in newly suitable area is enhanced by their high dispersal ability. As demonstrated by laboratory experiments (Smithers \& Smith, 1998) and observation in the field (Smithers, 2005b; Chiavazzo et al., 2015), in a specific phase of their life cycle these spiders are able to migrate outside the cave and spread through the air. Thanks to this airborne dispersal, they are able to colonise subterranean sites that are widely separated. It is clear that the potential northward expansion in the range of the two species will not only depend on their dispersal ability, but also upon the availability of suitable sub-surface habitats to colonise. However, as previously mentioned, the high ecological plasticity of these spiders suggests that the lack of suitable habitats will not represent an important limiting factor for their spread.

In general, model projections indicate that the climate of the British Isles is more suitable for $M$. menardi than $M$. bourneti - the latter being regarded as a Mediterranean species (Brignoli, 1971, 1972; Gasparo \& Thaler, 2000). It is thus reasonable to expect that $M$. menardi will primarily exploit suitable areas which will appear northward to their current distribution (Fig. 3), and M. bourneti will colonise empty niches left available by its congeneric.

It is well documented how climate changes can enhance invasion processes, causing the spread of alien species in novel habitats (Walther et al., 2009; Diez et al., 2012; Bellard et al., 2013), which may results in negative influences on native biological communities. However, I expect $M$. bourneti to have a limited impact on the distribution of its congeneric, because of the climatic limitations previously discussed. Moreover, $M$. bourneti represents the natural ecological vicariant of $M$. menardi, playing a similar role in subterranean trophic webs, thus having a limited impact on animal communities in caves. A comparable example is provided by the introduced troglophile rove-beetles Quedius mesomelinus (Coleoptera: Staphylinidae) which have become established in American caves, but have not displaced native species (see Peck \& Thayer, 2003).

As far as spiders are concerned, it is worth noticing that, in general, studies on alien species are rare (Kobelt \& Nentwig, 2008; Nentwig, 2015) and more so in the case of species able to live in subterranean habitats. In Europe, for instance, only three alien spiders have been found in subterranean habitats, namely Psilochorus simoni (Berland) (Araneae: Linyphiidae) (Kostanjšek \& Ramšak, 2005; Isaia et al., 2011; Nentwig et al., 2017), Nesticella mogera (Yaginuma) (Nentwig et al. 2017) and Eidmannella pallida (Emerton) (Araneae: Nesticidae) (Carles Ribera, pers. comm. 2016). Aside from caves, these species are also typically found associated with human habitats - e.g., greenhouses, cellars and buildings - and thus presumably spread by man. Notably, P. simoni was most likely introduced in Britain from France with the wine traffic (see Browning \& Thams, 1944; Harvey et al., 2002), presumably via the same route followed by $M$. bourneti.

\section{CONCLUDING REMARKS}

This is possibly the first attempt to forecast the current and future distribution of alien species in subterranean ecosystems. On the one hand, most British cave-associated species can be considered as introduced, because subterranean habitats in the British Isles have been actively undergoing recolonization ever since the Pleistocene glaciations (but see McInerney et al., 2014). On the other hand, still little is known about the routes and processes involved in this recolonization process. This specific case study of one of the most recently introduced species (Meta bourneti), highlights that transitional habitats at the epigean/hypogean interface might be one of the routes involved in the early stages of colonization of subterranean habitats.

It is clear that the two species of Meta in the British Isles represent a very specific case. Still, this study exemplifies a methodological approach that can be easily reproduced in other cases. More studies similar to this one could and would be useful when considering alien species which will have potentially negative impacts on native biological communities. For instance, the North American alien species Psilochorus simoni, being currently widely distributed in several subterranean sites across Europe (Nentwig et al., 2017), may represent the next promising candidate for spatial modelling and autecological field studies.

Predicting the distribution of subterranean species has also the potential to fill knowledge gaps, for instance by using inferred distribution maps to understand seemingly incomplete distribution data. This study could point to a way to analyse the records of other common subterranean species in the British Isles, including, but not restricted to, the two other widespread troglophile spiders Metellina merianae (Scopoli) (Tetragnathidae) and Nesticus cellulanus (Clerck) (Nesticidae) (SRS, 2017). In general, given the unique availability of extensive spatial datasets of species distribution for Great Birtain, provided by the Biological Records Centre (BRC), there is a strong potential for developing SDMs for a number of terrestrial and freshwater species, including subterranean ones (see e.g., the Hypogean Crustacean Recording Scheme; HCRS, 2017).

\section{ACKNOWLEDGMENTS}

For useful suggestions and his constant support I thank Marco Isaia. I am grateful to Peter Harvey, Paul Selden and all contributors to the UK Spider Recording Scheme team for making distribution data available. I am thankful to Peter Smithers, Carles Ribera and Fulvio Gasparo for useful consultancy regarding the life history of Meta spiders. Hsiao-Hsuan Rose Wang provided a number of constructive advices on a earlier 
version of the manuscript. I thank Alexandra Jones for proof-reading my English. Three anonymous referees provided helpful comments which significantly increased the quality of the manuscript.

\section{REFERENCES}

Allouche O., Tsoar A. \& Kadmon R., 2006 - Assessing the accuracy of species distribution models: prevalence, kappa and the true skill statistic (TSS). Journal of Applied Ecology, 43: 1223-1232. https://doi.org/10.1111/j.1365-2664.2006.01214.x

Badino G., 2010 - Underground meteorology. What's the weather underground? Acta Carsologica, 39 (3): 427448. https://doi.org/10.3986/ac.v39i3.74

Barve N., Barve V., Jiménez-Valverde A., Lira-Noriega A., Maher S.P., Peterson A.T., Soberón J. \& Villalobos F., 2011 - The crucial role of the accessible area in ecological niche modeling and species distribution modeling. Ecological Modeling, 222 (11): 1810-1819. https://doi.org/10.1016/j.ecolmodel.2011.02.011

Bellard C., Thuiller W., Leroy B., Genovesi P., Bakkenes M. \& Courchamp F., 2013 - Will climate change promote future invasions? Global Change Biology, 19 (12): 3740-3748. https://doi.org/10.1111/gcb.12344

Bregović P. \& Zagmajster M., 2016 - Understanding hotspots within a global hotspot-identifying the drivers of regional species richness patterns in terrestrial subterranean habitats. Insect Conservation and Diversity, 9: 268-281.

https://doi.org/10.1111/icad.12164

Brignoli P.M., 1971 - Note su ragni cavernicoli italiani (Araneae). Fragmenta entomologica, 7 (3): 129-229.

Brignoli P.M., 1972 - Catalogo dei ragni cavernicoli italiani. Quaderni di Speleologia del Circolo Speleologico Romano, 20: 1-211.

Brommer J.E., 2004 - The range margins of northern birds shifts polewards. Annales Zoologici, 41: 391-397. http://www.jstor.org/stable/23735946

Browning E. \& Tams W.H.T., 1944 - On the occurrence in Suffolk of a Western Mediterranean cavernicolous spider, Meta bourneti Simon (Araneae: Argyopidae). Proceedings of Linneian Society of London, 156: 95-96. https://doi.org/10.1111/j.1095-8312.1944.tb00378.x

Chen I.C., Hill J.K., Ohlemüller R., Roy D.B. \& Thomas C.D., 2011 - Rapid range shifts of species associated with high levels of climate warming. Science, 333: 1024-1026. https://doi.org/10.1126/science.1206432

Chiavazzo E., Isaia M., Mammola S., Lepore E., Ventola L., Asinari P. \& Pugno N.M., 2015 - Cave spiders choose optimal environmental factors with respect to the generated entropy when laying their cocoon. Scientific Reports, 5: 7611. https://doi.org/10.1038/srep07611 Chomphuphuang N., Deowanish S., Songsangchote C., Sivayyapram V., Thongprem P. \& Warrit N., 2016 The Mediterranean recluse spider Loxosceles rufescens (Dufour, 1820) (Araneae: Sicariidae) established in a natural cave in Thailand. Journal of Arachnology, 44 (2): 142-147. https://doi.org/10.1636/R15-61

Christman M.C. \& Culver D.C., 2001 - The relationship between cave biodiversity and available habitat. Journal of Biogeography, 28: 367-380. https://doi.org/10.1046/j.1365-2699.2001.00549.x

Christman M.C., Doctor D.H., Niemiller M.L., Weary D.J., Young J.A., Zigler K.S. \& Culver D.C., 2016 Predicting the occurrence of cave-inhabiting fauna based on features of the earth surface environment. PloS ONE, 11 (8): e0160408.

https://doi.org/10.1371/journal.pone.0160408
Culver D.C. \& Pipan T., 2009 - The biology of caves and other subterranean habitats. Oxford University Press, Oxford.

Diez J.M., D’Antonio C.M., Dukes J.S., Grosholz E.D., Olden J.D., Sorte C.J., Blumenthal D.M., Bradley B.A., Early R., Ibáñez I., Jones S.J., Lawler J.J. \& Miller L.P., 2012 - Will extreme climatic events facilitate biological invasions? Frontiers in Ecology and Environment, 10: 249-257. https://doi.org/10.1890/110137

Diniz-Filho J.A.F., Mauricio Bini L., Fernando Rangel T., Loyola R.D., Hof C., Nogués-Bravo D. \& Araújo M.B., 2009 - Partitioning and mapping uncertainties in ensembles of forecasts of species turnover under climate change. Ecography, 32 (6): 897-906. https://doi.org/10.1111/j.1600-0587.2009.06196.x

Elith J., Phillips S.J., Hastie T., Dudík M., Chee Y.E. \& Yates C.J., 2011 - A statistical explanation of MaxEnt for ecologists. Diversity and Distribution, 17: 43-57. https://doi.org/10.1111/j.1472-4642.2010.00725.x

Elliott W.R., 1992 - Fire ants invade Texas caves. American Caves, 5: 13.

Eme D., Zagmajster M., Fišer, C., Galassi, D., Marmonier, P., Stoch, F., Cornu J.F., Oberdorff T. \& Malard F., 2015 - Multi-causality and spatial non-stationarity in the determinants of groundwater crustacean diversity in Europe. Ecography, 37: 1-10.

https://doi.org/10.1111/ecog.01092

Eme D., Zagmajster M., Delić T., Fišer C., Flot J.F., Konecny-Dupré L., Pálsson S., Stoch F., Zakšek V, Douady C.J. \& Malard F., 2017 - Do cryptic species matter in macroecology? Sequencing European groundwater crustaceans yields smaller ranges but does not challenge biodiversity determinants. Ecography (in press). https://doi.org/10.1111/ecog.02683

Escobar L.E., Lira-Noriega A., Medina-Vogel G. \& Peterson T., 2014 - Potential for spread of the whitenose fungus (Pseudogymnoascus destructans) in the Americas: use of MaxEnt and NicheA to assure strict model transference. Geospatial health, 9 (1): 221-229. https://doi.org/10.4081/gh.2014.19

Fielding A.H. \& Bell J.F., 1997 - A review of methods for the assessment of prediction errors in conservation presence/absence models. Environmental Conservation, 24: 38-49.

https://doi.org/10.1017/S0376892997000088

Flory A.R., Kumar S., Stohlgren T.J. \& Cryan P.M., 2012 - Environmental conditions associated with bat whitenose syndrome mortality in the north-eastern United States. Journal of Applied Ecology, 49 (3): 680-689. https://doi.org/10.1111/j.1365-2664.2012.02129.x

Gasparo F. \& Thaler K., 2000 - I ragni cavernicoli del Venezia Giulia (Italia nord-orientale) (Arachnida, Araneae). Atti e Memorie della Commissione Grotte "E. Boegan", 37: 17-55.

Gerovasileiou V., Voultsiadou E., Issaris Y. \& Zenetos A., 2016 - Alien biodiversity in Mediterranean marine caves. Marine Ecology, 37 (2): 239-256.

https://doi.org/10.1111/maec. 12268

Harvey P.R., Nellist D.R. \& Telfer M.G., 2002 - Provisional atlas of British spiders (Arachnida, Araneae). Biological Records Centre, Huntingdon.

HCRS, 2017 - Hypogean Crustacean Recording Scheme. Freshwater Biological Association (organized by Knight L.) [accessed: July 18, 2017]. http://hcrs.freshwaterlife.org

Hijmans R.J., 2014 - raster: Geographic data analysis and modeling (data analysis software system), $\mathrm{R}$ package version 2.3-12.

http://CRAN.R-project.org/package=raster 
Hijmans R.J., Cameron S.E., Parra J.L., Jones P.G. \& Jarvis A., 2005 - Very high resolution interpolated climate surfaces for global land areas. International Journal of Climatology, 25 (15): 1965-1978.

https://doi.org/10.1002/joc. 1276

Hijmans R.J., Phillips S., Leathwick J. \& Elith J., 2014 - dismo: species distribution modeling, $\mathrm{R}$ package version $1.0-5$.

http: / / CRAN.R-project.org/package=dismo

Howarth F.G., James S.A., McDowell W., Preston D.J. \& Imada C.T., 2007 - Identification of roots in lava tube caves using molecular techniques: Implications for conservation of cave arthropod faunas. Journal of Insect Conservation, 11: 251-261. https://doi.org/10.1007/s10841-006-9040-y

Hulme P.E., 2009 - Trade, transport and trouble: managing invasive species pathways in an era of globalization. Journal of Applied Ecology, 46 (1): 10-18.

https://doi.org/10.1111/j.1365-2664.2008.01600.x

Isaia M., Paschetta M., Lana E., Pantini P., Schonhofer A.L., Christian E. \& Badino G., 2011 - Subterranean arachnids of the Western Italian Alps (Arachnida: Araneae, Opiliones, Palpigradi, Pseudoscorpiones). Monografie del Museo di Scienze Naturali, Torino.

Kobelt M. \& Nentwig W., 2008 - Alien spider introductions to Europe supported by global trade. Diversity and Distribution, 14 (2): 273-280.

https://doi.org/10.1111/j.1472-4642.2007.00426.x

Kostanjšek R. \& Ramšak L., 2005 - Psilochorus simoni (Berland, 1911)(Araneae, Pholcidae), a new record for Slovenian fauna from Postonjska jama cave. Natura Sloveniae, 7: 37-40.

Krosby M., Wilsey C.B., McGuire J.L., Duggan J.M., Nogeire T.M., Heinrichs J.A., Tewksbury J.J. \& Lawler J.J., 2015 - Climate-induced range overlap among closely related species. Nature Climate Change, 5 (9): 883-886. https://doi.org/10.1038/nclimate2699

Lunghi E., Manenti R. \& Ficetola G.F., 2017 - Cave features, seasonality and subterranean distribution of non-obligate cave dwellers. PeerJ, 5: e3169.

https://doi.org/10.7717/peerj.3169

Mammola S. \& Isaia M., 2014 - Niche differentiation in Meta bourneti and M. menardi (Araneae, Tetragnathidae) with notes on the life history. International Journal of Speleology, 43 (3): 343-353.

https://doi.org/10.1046/j.1461-0248.2003.00530.x

Mammola S. \& Isaia M., 2017a - Rapid poleward distributional shifts in the European cave-dwelling Meta spiders under the influence of competition dynamics. Journal of Biogeography (in press). https://doi.org/10.1111/jbi.13087

Mammola S. \& Isaia M., 2017b - Spiders in caves. Proceedings of the Royal Society B: Biological science, 284: 20170193.

https://doi.org/10.1098/rspb.2017.0193

Mammola S., Piano E. \& Isaia M., 2016a - Step back! Niche dynamics in cave-dwelling predators. Acta Oecologica, 75, 35-42.

https://doi.org/10.1016/j.actao.2016.06.011

Mammola S., Giachino P.M., Piano E., Jones A., Barberis M., Badino G. \& Isaia M., 2016b-Ecology and sampling techniques of an understudied subterranean habitat: the Milieu Souterrain Superficiel (MSS). The Science of Nature, 103: 88.

https://doi.org/10.1007/s00114-016-1413-9

Mammola S., Goodacre S.L. \& Isaia M., 2017 - Climate change may drive cave spiders to extinction. Ecography, 40: $1-10$.

https://doi.org/10.1111/ecog.02902
Manenti R., Lunghi E. \& Ficetola G.F., 2015 - The distribution of cave twilight-zone spiders depends on microclimatic features and trophic supply. Invertebrate Biology, 134 (3): 242-251.

https://doi.org/10.1111/ivb.12092

McInerney C.E., Maurice L., Robertson A.L., Knight L.R., Arnscheidt J., Venditti C., Dooley J.S.G., Mathers T., Matthijs S., Eriksson K., Proudlove G.S. \& Hänfling B., 2014 - The ancient Britons: groundwater fauna survived extreme climate change over tens of millions of years across NW Europe. Molecular Ecology, 23 (5): 1153-1166. https://doi.org/10.1111/mec. 12664

Milner E., 2013 - Cave spiders in the London area. Newsletter of the British Arachnological Society, 126: 18-20.

Martín J.L. Oromi P., 1984 - Consideraciones sobre la presencia de Schizomus portoricensis Chamberlin, 1922 (Arach. Schizomida) en cuevas de Tenerife (Islas Canarias). Boletin de la Asociacion Espanola de Entomologia, 8: 265-270.

Mazza G., Reboleira A.S.P.S., Goncalves F., Aquiloni L., Inghilesi A.F., Spigoli D., Stoch F., Taiti S., Gherardi F. \& Tricarico E., 2014 - A new threat to groundwater ecosystems: first occurrences of the invasive crayfish Procambarus clarkii (Girard, 1852) in European caves. Journal of Cave and Karst Studies, 76 (1): 62-65. https://doi.org/10.4311/2013LSC0115

Moseley M., 2007 - Acadian biospeleology: composition and ecology of cave fauna of Nova Scotia and southern New Brunswick, Canada. International Journal of Speleology, 36 (1): 1-18.

https://doi.org/10.5038/1827-806X.36.1.1

Moseley M., 2009a - Observations on the caveassociated beetles (Coleoptera) of Nova Scotia, Canada. International Journal of Speleology, 38 (2): 163-172. https://doi.org/10.5038/1827-806X.38.2.7

Moseley M., 2009 - Size matters: scalar phenomena and a proposal for an ecological definition of 'cave'. Cave and Karst Science, 35 (3): 89-94.

Moseley M. \& Proctor C., 2017 - An almost unknown subterranean habitat: British maritime terrestrial caves. Cave and Karst Science, 43 (3): 127-139.

Nentwig W., 2015 - Introduction, establishment rate, pathways and impact of spiders alien to Europe. Biological Invasions, 17 (9): 2757-2778.

https://doi.org/10.1007/s10530-015-0912-5

Nentwig W., Blick T., Gloor D., Hänggi A. \& Kropf C., 2017 - Spiders of Europe, Version 01.2017 [accessed: January 06, 2017]. http://www.araneae.unibe.ch

Novak T., Tkvac T., Kuntner M., Arnett E.A., Delakorda S.L., Perc M. \& Janžekovič F., 2010 - Niche partitioning in orbweaving spider Meta menardi and Metellina merianae (Tetragnathidae). Acta Oecologica, 36 (6): 522-529. https://doi.org/10.1016/j.actao.2010.07.005

Novak T., Perc M., Lipovšek S. \& Janžekovič F., $2012-$ Duality of terrestrial subterranean fauna. International Journal of Speleology, 41 (2): 181-188. https://doi.org/10.5038/1827-806X.41.2.5

Novak T., Šajna N., Antolinc E., Lipovšek S., Devetak D. \& Janžekovič F., 2014 - Cold tolerance in terrestrial invertebrates inhabiting subterranean habitats. International Journal of Speleology, 43 (3): 265-272. https://doi.org/10.5038/1827-806X.43.3.3

Oromí P. \& Martín J.L., 1992 - The Canary Islands subterranean fauna characterization and composition. In: Camacho A.I. (Eds.), The natural history of biospeleology. CSIC, Madrid, p. 527-556. 
Peck S.B. \& Thayer M.K., 2003 - The cave-inhabiting rove beetles of the United States (Coleoptera: Staphylinidae; excluding Aleocharinae and Pselaphinae): diversity and distribution. Journal of Cave and Karst Studies, 65 (1): 3-8.

Peterson A.T., Soberón J., Pearson R.G., Anderson R.P., Nakamura M., Martinez-Meyer E. \& Araújo M.B., 2011 - Ecological niches and geographical distributions. Princeton University Press, Princeton.

Phillips S.J., 2011 - A brief tutorial on MaxEnt. AT\&T Research, Princeton.

Phillips S.J., Anderson R.P. \& Schapire R.E., 2006 - Maximum entropy modeling of species geographic distributions. Ecological Modeling, 190: 231-259. https://doi.org/10.1016/j.ecolmodel.2005.03.026

Phillips S.J., Dudik M., Elith J., Graham C.H., Lehmann A., Leathwick J. \& Ferrier S., 2009 - Sample selection bias and presence-only distribution models: implications for background and pseudo-absence data. Ecological Applications, 19 (1): 181-197. https://doi.org/10.1890/07-2153.1

Pipan T., López H., Oromí P., Polak S. \& Culver D.C., 2011 - Temperature variation and the presence of troglobionts in terrestrial shallow subterranean habitats. Journal of Natural History, 45: 257-273. https://doi.org/ 10.1080/00222933.2010.523797

Price L., 2016 - An introduction to some cave fauna of Malaysia and Thailand. Acta carsologica, 33 (1): 311 317. https://doi.org/10.3986/ac.v33i1.359

Price L. \& Steiner H., 1999 - Periplaneta australasiae (Blattidae), a new record for Dark Cave, Batu Caves. Malayan Nature Journal 53 (4): 341-344.

Prous X., Ferreira R.S. \& Martins R.P., 2004 - Ecotone delimitation: Epigean-hypogean transition in cave ecosystems. Austral Ecology, 29: 374-382.

https://doi.org/10.1111/j.1442-9993.2004.01373.x

Prous X., Lopes Ferreira R. \& Jacobi C.M., 2015 - The entrance as a complex ecotone in a Neotropical cave. International Journal of Speleology, 44 (2): 177-189. https://doi.org/10.5038/1827-806X.44.2.7

Pyšek P., Bacher S., Chytrý M., Jarošík V., Wild J., Celesti-Grapow L., Gassó N., Kenis M., Lambdon P., Nentwig W., Pergl J., Roques A., Sádlo J., Solarz W., Vilà M. \& Hulme P.E., 2010 - Contrasting patterns in the invasions of European terrestrial and freshwater habitats by alien plants, insects and vertebrates. Global Ecology and Biogeography, 19: 317-331.

https://doi.org/10.1111/j.1466-8238.2009.00514.x

Růžika V., 1999 - The first steps in subterranean evolution of spiders (Araneae) in Central Europe. Journal of Natural History, 33: 255-265.

https://doi.org/10.1080/002229399300407

Růžika V. \& Klimeš L., 2005 - Spider (Araneae) communities of scree slopes in the Czech Republic. Journal of Arachnology, 33: 280-289.

https://doi.org/10.1636/04-44.1

Sánchez-Fernández D., Rizzo V., Cieslak A., Faille A., Fresneda J. \& Ribera I., 2016 - Thermal niche estimators and the capability of poor dispersal species to cope with climate change. Scientific Reports, 6: 23381.

https://doi.org/10.1038/srep23381

Saupe E.E., Barve V., Myers C.E., Soberón J., Barve N., Hensz C.M., Peterson A.T., Owens H.L. \& Lira-Noriega A., 2012 - Variation in niche and distribution model performance: the need for a priori assessment of key causal factors. Ecological Modelling, 237: 11-22. http://dx.doi.org/10.1016/j.ecolmodel.2012.04.001

Smithers P., 1995 - Some observations on the distribution of Meta menardi (Latreille) in disused mines in SW Devon. Newsletter of the British Arachnological Society, 73: 6.
Smithers P., 2005a - The diet of the cave spider Meta menardi (Latreille 1804) (Araneae, Tetragnathidae). Journal of Arachnology, 33: 243-246. https://doi.org/10.1636/CT-05-2.1

Smithers P., 2005b - The early life history and dispersal of the cave spider Meta menardi (Latreille, 1804) (Araneae: Tetragnathidae). Bulletin of the British Arachnological Society, 13 (6): 213-216.

Smithers P. \& Smith F.M., 1998 - Observations on the behaviour of second instars of the cave spider Meta menardi (Latreille, 1804). Newsletter of the British Arachnological Society, 81: 4-5.

SRS, 2015 - Spider and Harvestman Recording Scheme. British Arachnological Society [accessed: January 1, 2015]. http://srs.britishspiders.org.uk

SRS, 2017 - Spider and Harvestman Recording Scheme. British Arachnological Society [accessed: July 17, 2017]. http://srs.britishspiders.org.uk

Syfert M.M., Smith M.J. \& Coomes D.A., 2013 - The effects of sampling bias and model complexity on the predictive performance of MaxEnt Species Distribution Models. Plos One, 8 (2): e55158. https://doi.org/10.1371/journal.pone.0055158

Taylor S.J., Krejca J., Smith J.E., Block V.R. \& Hutto F., 2003 - Investigation of the potential for red imported fire ant (Solenopsis invicta) impacts on rare karst invertebrates at Fort Hood, Texas: A field study. Center for Biodiversity, Technical Report no. 28.

Trajano E. \& de Carvalho M.R., 2017 - Towards a biologically meaningful classification of subterranean organisms: a critical analysis of the Schiner-Racovitza system from a historical perspective, difficulties of its application and implications for conservation. Subterranean biology, 22: 1-26. https://doi.org/10.3897/subtbiol.22.9759

Warren D.L., Glor R.E., Turelli M. \& Funk D., 2009 Environmental niche equivalency versus conservatism: quantitative approaches to niche evolution. Evolution, 62: $2868-2883$.

https://doi.org/10.1111/j.1558-5646.2008.00482.x

Warren R.J., Chick L.D., DeMarco B., McMillan A., De Stefano V., Gibson R. \& Pinzone P., 2016 - Climatedriven range shift prompts species replacement. Insectes Sociaux, 63 (4): 593-601.

https://doi.org/10.1007/s00040-016-0504-0

Walther G.-R., Post E., Convey P., Menzel A., Parmesan C., Beebee T.J.C., Fromentin J.-M., Hoegh-Guldberg O. \& Bairlein F., 2002 - Ecological responses to recent climate change. Nature, 416: 389-395.

https://doi.org/10.1038/416389a

Walther G.-R., Roques A., Hulme P.E., Sykes M.T., Pysek P., Kühn I., Zobel M., Bacher S., Botta-Dukát Z., Bugmann H., Czúcz B., Dauber J., Hickler T., Jarosík V., Kenis M., Klotz S., Minchin D., Moora M., Nentwig W., Ott J., Panov V.E., Reineking B., Robinet C., Semenchenko V., Solarz W., Thuiller W., Vilà M., Vohland K. \& Settele J., 2009 Alien species in a warmer world: risks and opportunities. Trends in Ecology and Evolution, 24: 686-693. https://doi.org/10.1016/j.tree.2009.06.008

Wynne J.J., Bernard E.C., Howarth F.G., Sommer S., Soto-Adames F.N., Taiti S., Mockford E.I., Horrocks M., Pakarati L. \& Pakarati-Hotus, V., 2014 - Disturbance relicts in a rapidly changing world: the Rapa Nui (Easter Island) factor. BioScience, 64 (8): 711-718. https://doi.org/10.1093/biosci/biu090

Zagmajster M., Eme D., Fišer C., Galassi D., Marmonier P., Stoch F., Cornu J.-F. \& Malard F., 2014 Geographic variation in range size and beta diversity of groundwater crustaceans: insights from habitats with low thermal seasonality. Global Ecology and Biogeography, 23 (10): 1135-1145.

https://doi.org/10.1111/geb.12200 
Zuckerberg B., Woods A.M. \& Porter W., 2009 - Poleward shifts in breeding bird distributions in New York State. Global Change Biology, 15: 1866-1883.

https://doi.org/10.1111/j.1365-2486.2009.01878.x
Zuur A.F., Ieno E.N. \& Elphick S.C., 2010 - A protocol for data exploration to avoid common statistical problem. Methods in Ecology and Evolution, 1: 3-14. https://doi.org/10.1111/j.2041-210X.2009.00001.x 